\title{
Analysis of transmission of conditional volatility from market risk factors
}

\begin{abstract}
Análisis de transmisión de volatilidad condicional de factores de riesgo de mercado
\end{abstract}

Antonio Ruebn Santillan Pashma. ${ }^{1}$

Recibido: 21-02-2021 / Revisado: 29-02-2021 /Aceptado: 22-03-2021/ Publicado: 05-04-2021

\begin{abstract}
DOI: https://doi.org/10.33262/concienciadigital.v4i2.1700

This article aims to understand the transmission of volatility from the main market indicators of the European financial system, towards market interest rates, focusing on the prices of the swap with maturity of one year and payments of three months as endogen variable and the three main indexes of the European market as CAD, DAX3, and IBEX35, as an exogenous variable. The exogenous will absorb all the necessary information from the market agents as companies, banks, investments funds, or from externals disturbances as European Central Banks and will affect the levels and the slope of the swap prices.
\end{abstract}

Introduction. SWAP is the financial instrument that will be employed to analyze the changes of the volatility in the market because it is the bigger derivative inside of the group of Fixed Income Assets. It is with the greatest depth and liquidity being one of the best instruments for developing market strategies of investment. Aim. Analyst the transmission of volatility from the systematic risk, represented by indices of the market, through the swap prices. Results. DAX30 and CAD transference of volatility are positive, in the particular case of the CAD the effect of transference is significantly positive and extended because the coefficient is greater than 1. IBEX35 provides an extended negative correction. Meaning for every one percentage point change in the IBEX35, It can be expected on average that the volatility of the swap will move in -4.19 percentage point. Conclusion: The slope of the curve o the endogen variables will be determined by the transmission of the volatility from the exogenous variables and the correlation level of the endogenous will adopt with each index

\footnotetext{
${ }^{1}$ Faculty of Organizational and Management Science, Szent István University Kaposvár, Guba Sándor u. 40, 7400 Kaposvar - Hungary, e-mail: santillan.antonio@ke.hu, https://orcid.org/0000-0001-6696-8127
} 
Keywords: Volatility, GARCH, SWAP, Index.

JEL codes: G120, G230, B230

\section{Resumen}

Este artículo tiene como objetivo comprender la transmisión de la volatilidad de los principales indicadores de mercado del sistema financiero europeo, hacia los tipos de interés de mercado, centrándose en los precios del swap con vencimiento a un año y pagos a tres meses como variable endógena y los tres índices principales. del mercado europeo como CAD, DAX3 e IBEX35, como variable exógena. Los exógenos absorberán toda la información necesaria de los agentes del mercado como empresas, bancos, fondos de inversión o de perturbaciones externas como los Bancos Centrales Europeos y afectarán los niveles y la pendiente de los precios de los swap.

Introducción. SWAP es el instrumento financiero que se utilizará para analizar los cambios de volatilidad en el mercado por ser el derivado más grande dentro del grupo de Activos de Renta Fija. Es con mayor profundidad y liquidez siendo uno de los mejores instrumentos para desarrollar estrategias de mercado de inversión. Apuntar. Analizar la transmisión de la volatilidad del riesgo sistemático, representado por índices de mercado, a través de los precios swap. Resultados. La transferencia de volatilidad del DAX30 y CAD son positivas, en el caso particular del CAD el efecto de la transferencia es significativamente positivo y extendido porque el coeficiente es mayor que 1. IBEX35 proporciona una corrección negativa extendida. Es decir, por cada cambio de un punto porcentual en el IBEX35, se puede esperar en promedio que la volatilidad del swap se mueva en -4,19 punto porcentual. Conclusión: La pendiente de la curva de las variables endógenas estará determinada por la transmisión de la volatilidad de las variables exógenas y el nivel de correlación de las endógenas adoptará con cada índice.

Palabras clave: Volatilidad, GARCH, SWAP, Índice.

Códigos JEL: G120, G230, B230

\section{Introduction}

The swaps are working in regulated stock markets, as this market represents a small percentage of the market trading activities and O.T.C (Over the Counter) markets; however, the nonregulation markets or OTC represents the biggest part of the negotiation. Where the traders can negotiate all the aspects of the contract: maturity, the percentage of the interest rate, the amount of capital, risk premium, among others (Robert $\mathrm{N}$ McCauley 1998.)

Furthermore, it is necessary to highlight the analysis of market risk, systematic risk, or diversifiable risk, depending on the author's criteria (Carsten Detken / Philipp Hartmann. 
2008). Market risk is created by interdependencies between the companies who are operating in the same system or market, in which the failure of an entity or group of entities can cause a cascade failure of the market (Big Banks Accused of Monopolizing Interest Rate-Swap Market 2015).

The movements of the companies who are interrelated within the market are collected through market indicators or indexes; if the index suffers strong contractions or strong rises can collapse the system or overvalue the market with the possibility of generating fictitious yields. These indicators collect in their daily prices, all the necessary information to explain the performance of the main companies in the eurozone, providing information about their business level and tendencies of performance, being able to alert the European momentary authority (European Central Bank). There are several indicators in the European Union but the three main are CAD German, DAX30 French, and IBEX35 in Spain, these indicators can represent the consistency of the European market, the German indicator is one of the less volatile and with the highest turnover, the DAX30, IBEX35 are more volatile indicators and with the high turnover that explain the movements of the euro as the common currency.

If the European central bank moves the interest rate, forward rates also change, and with it the swap prices. It has been affected by the increase of the market volatility and how it has been already mentioned in times of high instability forward rates are not capable to estimate Interest rate swap, IRS rates as unbiased estimators. It can be observed how the volatility increases when quantitative easing policies interrupt markets, forcing to offer asset with profitability negative, like German bonds with negative interest rate. Since the volatility is transferred to the IRS (De La Torre Gallegos, A 1996). Because investors are looking for bonds with negative returns, there are several reasons why to invest in these bonds. On the one hand, for speculative reasons, it may be a good opportunity if we foresee that prices will continue to fall or, on the contrary, they will experience an increase.

On the other hand, we can find benefits caused by the exchange rate, capital gain forecast, or by foreseeing the future demand and supply, or because you do not want to expose yourself to total losses with bonds that offer positive returns, but with a high risk of default. These are the main reasons why it is so convenient to anticipate or understand the market movements and to be able to develop a model that explains these increases or decreases in volatility of the swap (Robert F. Engle, 1999).

\section{Literature Review}

Using the increase of volatility as a perturbation of the market Paul R. Masson and Bart G. Turtelboom (1997), have used the use to analyze the stability of the currency as the key for the success of the European Economic and Monetary Union. Although there is no decision about the monetary policy framework, yet it is probably going to include either money or inflation targeting. Under both policy rules, the outcome is compared by stochastic simulations for macroeconomic and financial variables to analyze the effect of 
replacing the European currencies with the euro. According to the results, the macroeconomic variables should stay stable although structural changes are not made.

While the concentration of liquidity in the future markets in the German government bond brings a measure of integration to the euro government bond market, the disproportion of futures and cash market may leave the euro government bond market less liquid than it might be otherwise. Richard Portes and Helene Rey (1998) found that the euro might take on roles of the dollar while assessing the plausibility of the three-region world model and the implications for economic efficiency with forex and security market data as the welfare analysis revealed potential quantitatively significant benefits for the euro area.

Once we have analyzed the market disturbances and volatility increases, we will finish this dissertation by talking about the transmission of instability from the markets to interest rates, therefore Dyl and Joehnk (1981), using a week sample of the t-bills prices shows us how the riding strategies are more profitable than to use a benchmark strategy, the authors have been used t-bills because that market isn't volatility, more liquidity and efficient. They assume that the curve of the interest rates is stable and they use the security margin as the filtering rule. The margin security is a measure of the steepness of the slope curve. And we can define the percentage difference between forwarding interest rates and the discount factor of fixed income.

Briefly, it is noticeable, that they developed a model where they could find that the discrete regime shifts have as their subordinates the short interest rate and the market price of risks.

Consequently with this idea Fabio Fornari (2005), in his article "The rise and fall of US dollar interest rate volatility: evidence from swaptions"; he expresses that the interest rate volatility that emerges from the swaptions prices increased in all major economic areas more than the euro rates between 2001 and before the spring of 2004 because, after the beginning of the year 2004, the volatility of the US dollar has decreased. Through his article, the author distinguishes between the expected volatility and the volatility risk, and he analyzes if the rise of the interest rate volatility had a relationship with the expected volatility or with the compensation that comes with the volatility risk, and the results of Fornari, shows that between 2001and the first months of 2004, the volatility of the dollar caused a substantial compensation for risk, what after made decreased it significantly.

Examining the forex market for its high volatility and transmission to other indicators (Carten Detken and Philipp Hartmann, 2000) examined the role of the major currencies with higher importance on the first year of the euro not only for international financing but also for international investment, with several key factors determining how international portfolio investments distribute. For international financing and investment, the euro became the second most used currency in almost all important market segments, slightly overtaking the US dollar in the second half of 1999, although early external asset supply is absorbed by euro area residents. Lorenzo Cappiello and Peter Hördahl (2006) measured the integration of the European financial markets with GARCH correlations and a regression quantile-based codependence. In both equity and bond area markets an 
increase in co-movements was documented as an indication of a progressing integration. However, co-movements in equity markets indicate a limited increase only to large euro area economies.

The dynamic no-arbitrage term structure model is to examine the pricing implications of the euro. The analysis shows a decreased variability of premia as a result of smaller macro shocks, and as factors influence the dynamics of premia still after the introduction of the euro. Michael G. Kollo (2005) has found a significant but declining association between the home market of the currency of denomination and the lead underwriter. The competitive landscape for underwriting services was rearranged by the amalgamation of the European currencies, shifting from European underwriters to U.S. Underwriters causing an increase of the new issues declining the gross underwriter spread.

\section{Analysis of Volatility}

\section{Methodology and Data}

The data that is going to be used to analyze the transfer of volatility from the market to the interest rate swap will be the main market indicators in the eurozone collected in discrete intervals of time. The indicators represent different segments of the European economy, DAX30 represents the German economy, CAD-40 includes the most significant companies inside of the French economy and finally, the IBEX-35 includes the companies with the highest turnover inside of the Spanish economy. Data were taken daily from 02/01/2004 to 09/06/2016, as explicative variables which are transferring volatility to the independent variable as the interest rate SWAP, 3 months payments with one year of maturity (SWAP3m1Y), SWAP3m1Y variable has been estimated with the theory of expectations, using EURIBOR and the implicit forwards. The data investigation is coming from the three main indicators

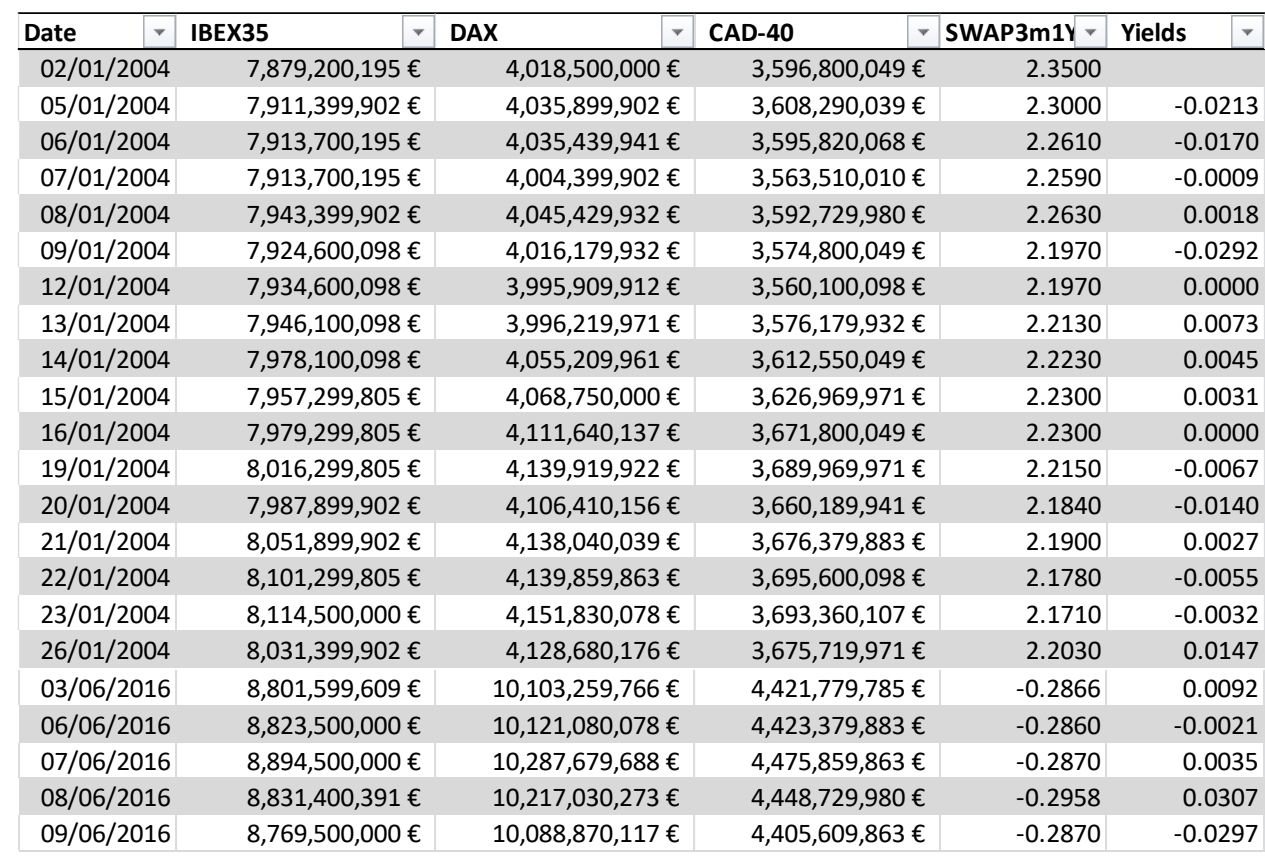

Source: European Central Bank and Bloomberg

Figure 1 Daily price quotes of European indexes. 


\section{$\underline{\text { Not Stationary in Mean }}$}

Where $\alpha$ indicates the ARCH effect associated with the residual of the ARIMA model considered and $\beta$ captures the persistence in volatility. Once the model is selected the series has to complete the following requirements, the times series has to be: Stationaries in mean, No stationaries in variance. In Figure 1, we can observe that the series have a cyclical component and it is not stationary in its mean, since it tends the series have to be transformed.
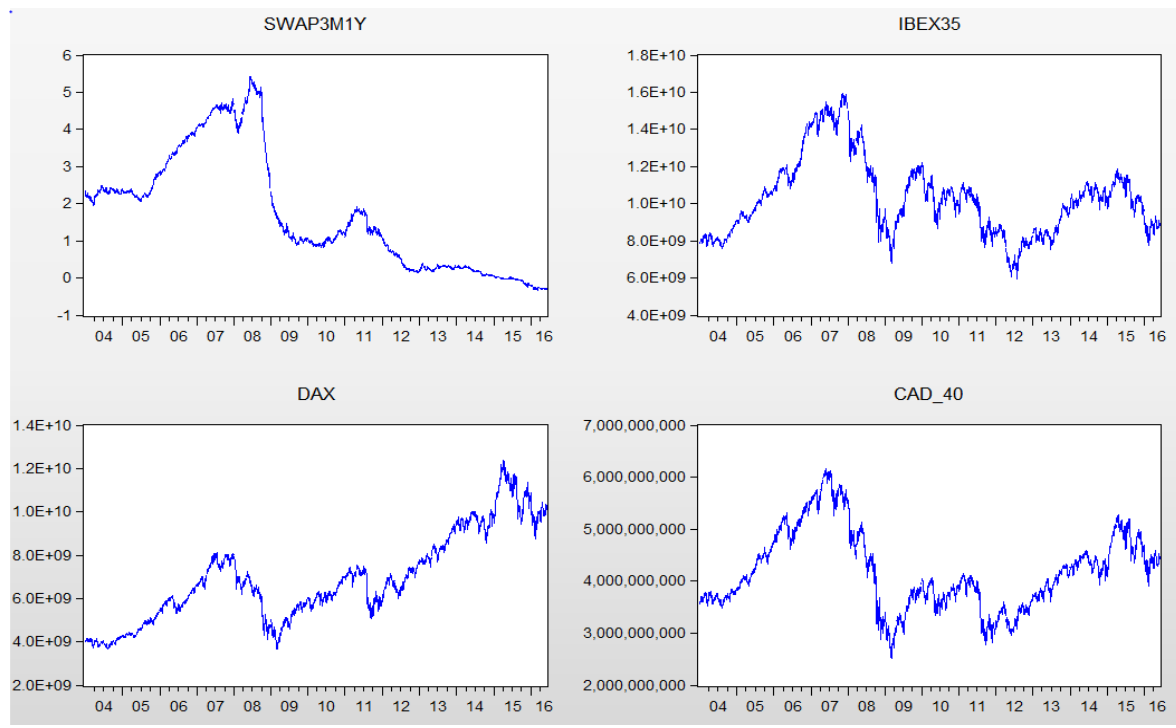

Source: Graph created by E-Views

Figure 2 European indexes.

Because the series is not stationary in mean, the series has been transformed in yields. Once the transformation is complete, we have to check, if the new series is stationary in a mean. The tendency assumption of the previous section can be corroborated using the unit root test, which for a significance of 5\% level, we have to accept the null hypothesis and conclude that series are not stationaries in mean p-values are lower than 0.05 .

To demonstrate the not stationary It was used one of the most popular test Dickey-Fuller, for autoregressive and random walk models, stochastic processes can include or exclude a constant term and can include or exclude a time trend. In the model, the Constant and Linear trend was included. The null and alternative hypotheses, if we do not reject the null hypothesis that $\rho=0$, we conclude that the series is nonstationary in a mean. If we reject the null hypothesis that $\rho=0$, we conclude that the series is stationary a mean.

We observe that the distribution that most closely resembles the frequency histogram provided by the indexes series is the Normal distribution. The parameters obtained are the following for a 95\% confidence interval. We cant reject the null hypothesis and the times series are is nonstationary in a mean: 

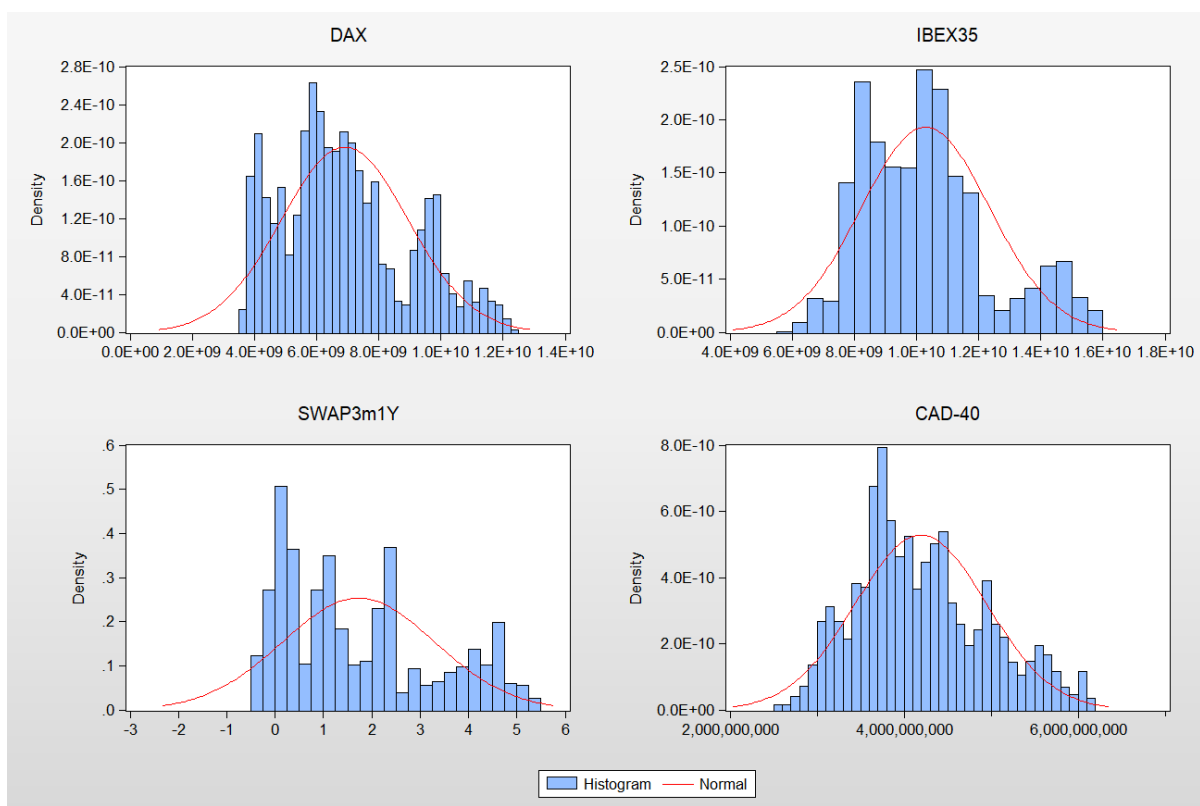

$\square$ Histogram - Normal

Source: Graph created by E-Views

Figure 3 Histogram Normal Probability Distribution.

The original series was transforming to their first logarithmic difference given their nonstationarity in levels:

$$
R_{i}=\log \left(\frac{P_{i}}{P_{i-1}}\right)
$$

Source: Hull (2015)

\section{Log returns}

\section{Equation 1}

Where $\mathrm{Ri}$ is the return of the asset in the I moment and $\mathrm{Pi}$, is the price of the index or interest rate in the I moment and Pi-1 is the price of one trading day before. On graph 18, we can observe how the series has been transformed in the first difference and it can be observed that the tendency has disappeared and the and the series has a reversion to the mean required by the GARCH model.

To proceed with the analysis of the first statistical moments of the selected variables, in the first place, the corresponding update of interest rates has been carried out using the update factor in discrete-time 1/ $(1+\mathrm{R}(1))$, It would give us the same result as if the continuous-time update factor $\mathrm{e}^{-\mathrm{R}(1)}$ were applied. Through the updates, the daily returns of each of the data series have been calculated by applying their corresponding transformation into Naperian logarithms, LN (Pt / Pt-1).

The variance of each of the series has been calculated as the mathematical expectation of the square of the deviations between the values of the variable and its mathematical expectation. The standard deviation is the square root of the variance, taken with a positive sign. Annualization can be achieved from the volatilities calculated for each period of a certain frequency, without more than multiplying by the square root of the number of data of that frequency in a year. 
Therefore, inevitably, the annualized volatility is higher than both the variance and the standard deviation since it is a function of the time horizon. In the time series of financial instruments, which follow a Gaussian random walk, volatility increases according to the square root of the time horizon. The longer the time interval considered, the greater the annualized volatility. However, the size of the sample does not condition the estimate. As can be seen in Figure 4, the annualized volatility is much higher than the sample variance as a consequence of the effect of the time horizon in the calculation of the previous. If we analyze the time series of the volatilities of the indexes, greater volatility can be seen in periods of greater economic uncertainty, mainly during the economic crisis in the United States (2008) and, in particular, due to the possible bankruptcy of Goldman Sachs investment group. When drawing financial conclusions, it is important to assess the data obtained since if we took into account the variance to calculate the risk of said financial instrument, we could conclude that each of them presents a very low risk. However, if we consider the annualized volatility, the instruments have a much higher risk, which could lead us to an equivocal conclusion.

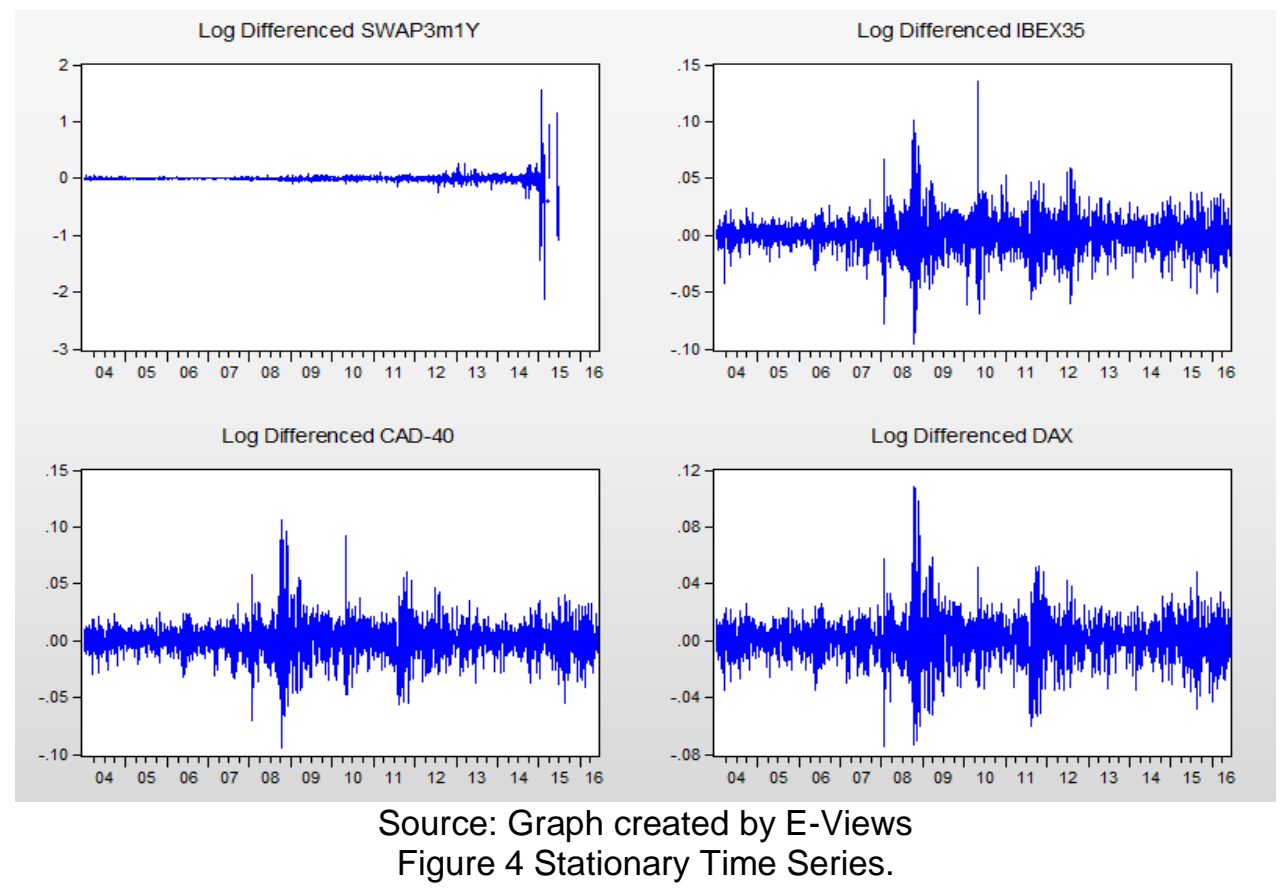

Model is stationary in mean:

Once the series is stationary in a mean. As the second step, it has to identify the not stationary in variance. The ARCH (Autoregressive Conditional Heteroscedasticity) and GARCH (Generalized Autoregressive Conditional Heteroscedasticity) models considered by Engle [1982] and Bollerslev [1986], provide us and specific tool to generate estimations of the volatility in a short time. On the other hand, when variances are NO conditionals the It could generate predictions in long term.

The volatility estimation is carried out from multivariate GARCHs that allow estimating the volatility of each variable separately without losing the joint dynamics of the system, 
and verifying if there is a contagion of fiscal volatility on the levels and volatilities of the other variables considered (Bollerslev, 1986)

To identify the AR model that the series follows, We have to identify if the serie depends on the constant or it depends on the lags, with the correlogram :

$$
y_{t}=\beta_{0}+\beta_{1} y_{t-1}+\beta_{2} y_{t-2}+\cdots+\beta_{n} y_{t-n}+u_{t}
$$

Significance test, to identify GARCH effects: The variance depends on the past innovations and depends on the past variance.

$$
h_{t}=\propto_{0}+\sum_{i=1}^{p} \propto_{i} \varepsilon_{t-i}^{2}+\sum_{i=1}^{q} \beta_{i} h_{t-1}
$$

Source: Econometric Models (2015)

\section{GARCH Model}

Where

$0 \leq \sum_{i=1}^{p} \propto_{i} \leq 1-$ Confirm Stacionarity in mean

$\sum_{i}^{p}\left(\propto_{i}+\beta_{i}\right)<1-$ The variance does not raise to infinitive

Test of Significance

$H_{0}=\propto_{1}, \beta_{1}=0, \propto_{2}, \beta_{2}=0 \ldots \propto_{n}, \beta_{n}=0$ - Homocedastic

$H_{0} \neq \propto_{1}, \beta_{1} \neq 0, \propto_{2}, \beta_{2} \neq 0 \ldots \propto_{n}, \beta_{n} \neq 0$ - Heterocedastic

$\propto_{0}>0 \quad \propto_{j} \geq 0 \beta_{j} \geq 0$ - Positive Variance

$\propto_{i}, \beta_{i}>\propto_{j}, \beta_{j}$ for $i>j-$ The most recent past is more important

\section{Equation 6}

Figure 13 it can be observed that the model follows an $\mathrm{ARCH}(1)$ observing the autocorrelogram. We observe little autocorrelation in each of the series, both with partial and simple autocorrelation, all values are within the confidence bands. It should be noted that there is an auto-relationship of order 1 in the interest rate series, ARMA1 autocorrelation, both partial and simple.

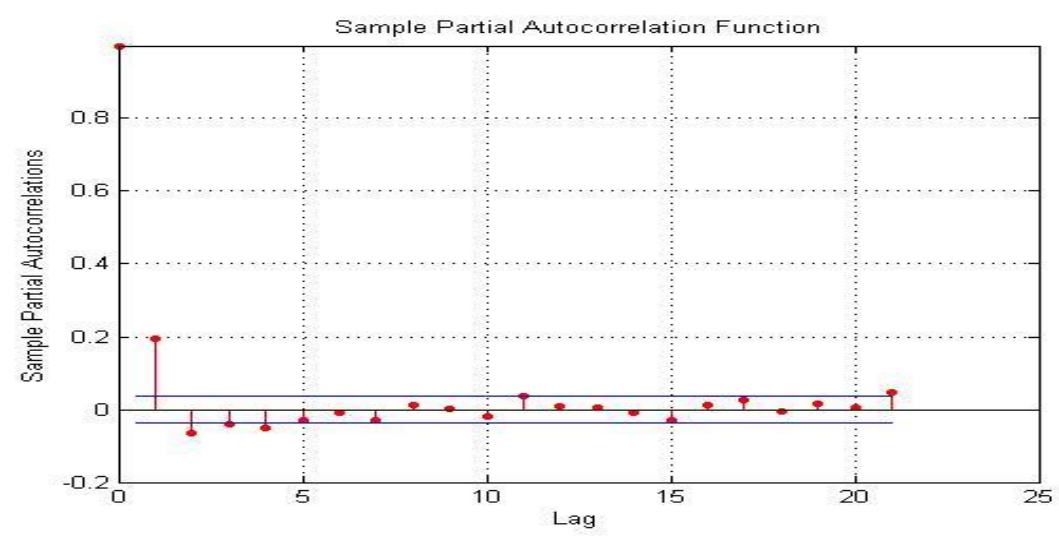

Source: Graph created by E-Views

Figure 5 Autocorrelation Figure SWAP prices. 
We can observe that the Figure has a trend component; the model requires that it be stationary in its mean. In order, to use the GARCH model we have to determine if the times series are heteroscedastic, not stationary in variance and stationary in mean. To demonstrate the not stationary in variance, it has been tested with the heteroscedastic test, it has been changed the variables in yields and we have run the unit roof test (Carte Hill, Willian Griffiths, Guay Lim, 2011, page 298).

In figure number 6 , it can be observed that the p-values are significantly lower than 0.05 , the sum of the parameters are lower than 1 and all the variables are positives. Once the model has been tested the no stationarity in variance, can use the DCC to estimate the equation that allows the model to understand the transmission of volatility from the market to the interest rate swaps. In the following graphical: it can be observed the conditional variance of each variable. To generate projections in short term, the conditional variable will take into consideration the changes of the volatility in each period, the analysis of projections is not part of this dissertation but it has to be take considered for futures analysis.

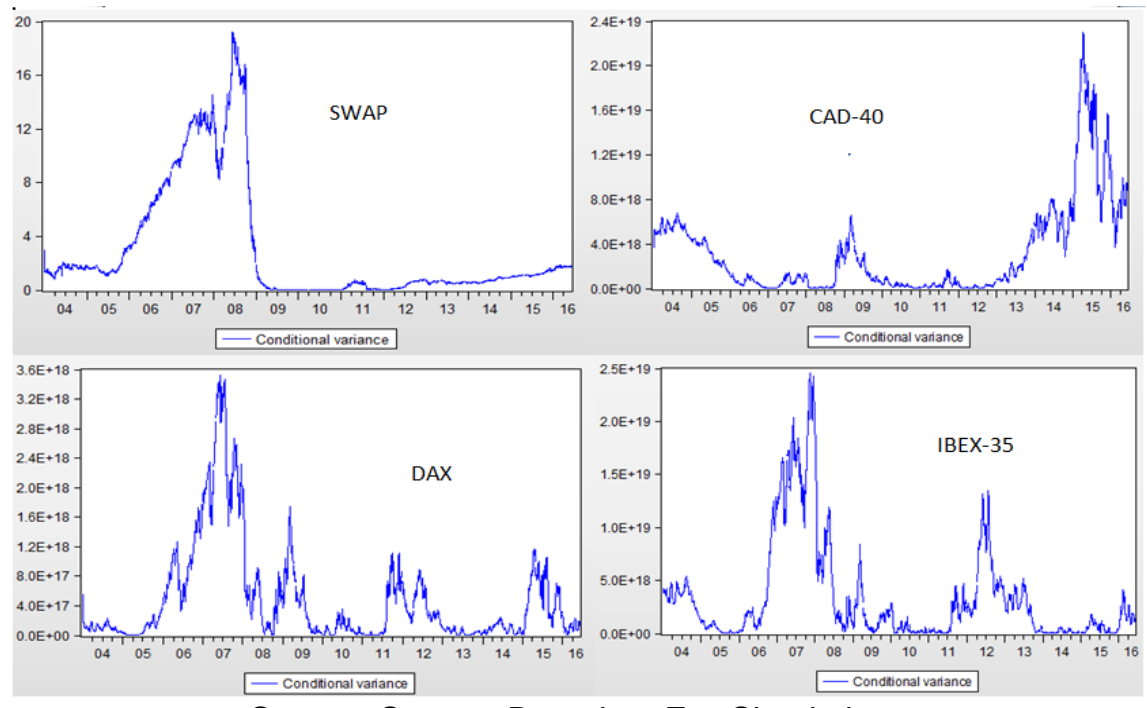

Source: Source: Based on E-< Simulations

Figure 6 Conditional Volatility of each variable

Using structural multivariable DCC- GARCH (Dynamic Conditional Correlation) model (Engle and Sheppard,2001), it be analyzed the transference of volatility between different time's series; observing how the main indicators of the market risk are influencing the prices of the SWAP interest rates of 3-month payment with 1year of maturity. The volatility can be defined as the conditional variance of the subjacent variable in our case the indices of the European market. To carry out this estimation we need to arrive at the final equation that will provide us with the volatility transfer:

\section{Results and Conclusions}

Once the model has been settle and estimated. It can be observed that all the coefficients of the model are significant with a p-value of 0.05 . That means based on the estimation 
that exists transmission of volatility from the market to the interest rate with changes of the volatility of one of the variables will expect changes in the volatility of the swap.

$$
\begin{gathered}
\delta^{2}=w+\alpha R_{S W A P_{t-1}}^{2}+\beta_{1} \delta_{S W A P_{t-1}}^{2}+\beta_{2} \delta^{2}{ }_{I B E X_{t-1}}+\beta_{3} \delta^{2}{ }_{D A X_{t-1}}+\beta_{4} \delta^{2}{ }_{C A D_{t-1}} \\
\text { Source: Equation created by Stata } \\
\text { DCC - GARCH Model }
\end{gathered}
$$

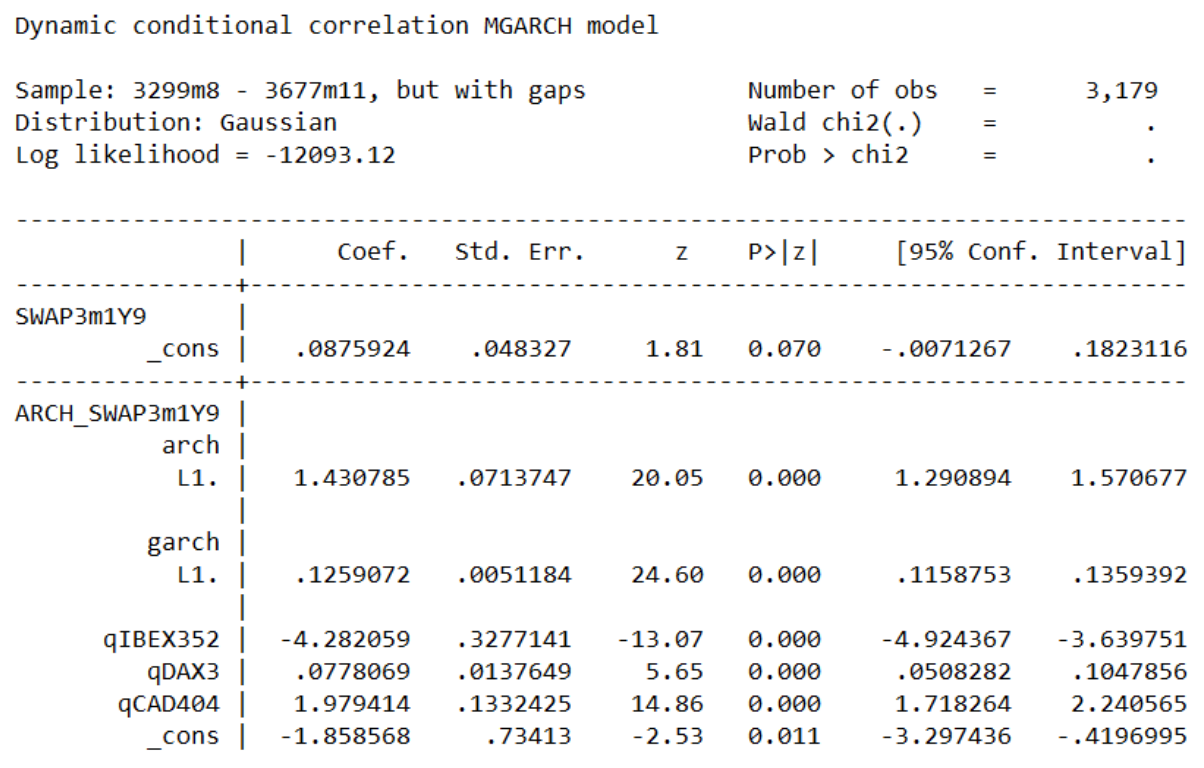

Source: Output Stata Calculation

Figure 7 DCC -GARCH MODEL

In the case of DAX30 and CAD the transference of volatility is positive, in the particular case of the CAD the effect of transference is significantly positive and extended because the coefficient is greater than 1. Meaning for every one percentage point change in the CAD, It can be expected on average the volatility of the swap will raise by 1.94 percentage point extended. The reason for this extended transference can be observed for the higher correlation that the variable present with the SWAP, in Figure 28 the average of this correlation is in average positive and greater than 0.5 what shows that the French market is highly exposed to the prices of the SWAP because of turnover volume that this market plays in the eurozone.

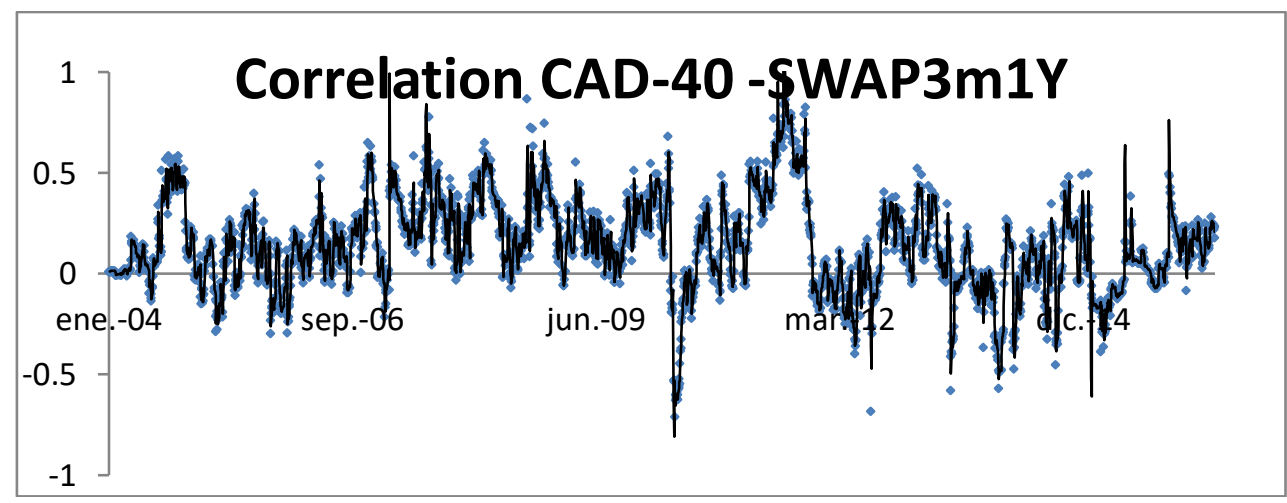

Source: Based on Matlab Simulation

Figure 8 Correlations CAD -SWAP 
The DAX30 although offerings a positive correlation and exist transition of volatility from the market to the swap prices. It can be observed that on average the correlation is no significant because the market isn't so volatile as the French market and it can be concluded that is no too much exposed to the movement of the swap prices as can be observed in Figure 9.

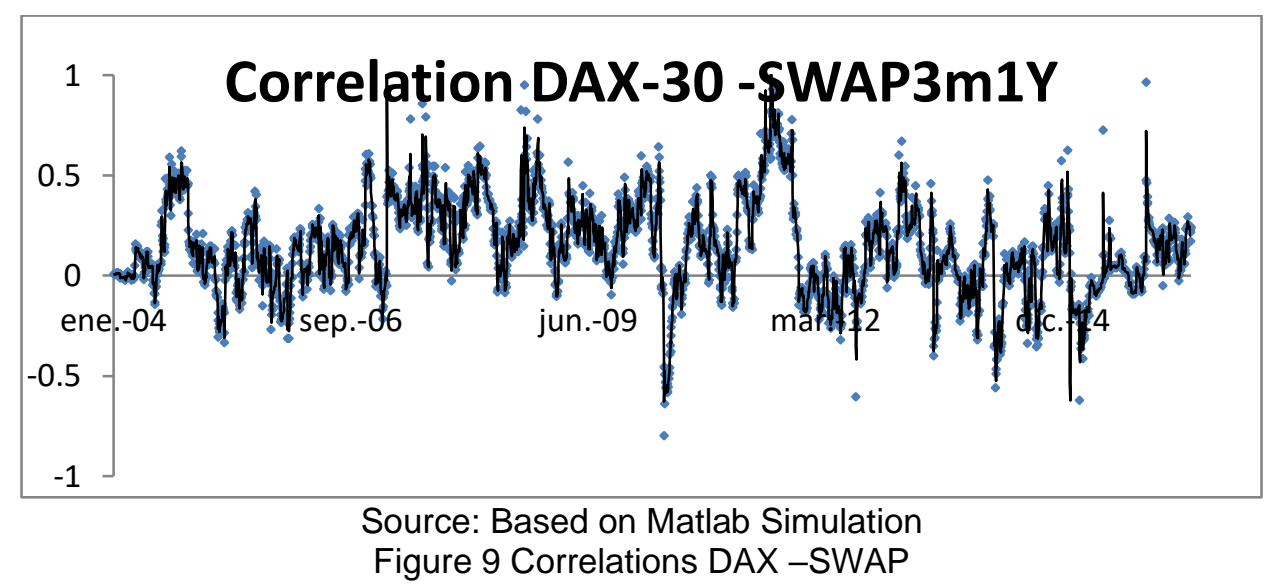

Finally, IBEX35 is providing an extended negative correction. Meaning for every one percentage point change in the IBEX35, It can be expected on average that the volatility of the swap will move in -4.19 percentage point. This very pronounced transfer of volatility is due to the great uncertainty that the Spanish market has had since the 2012 attack on government bonds leading to a scenario of uncertainty about the continuity in the eurozone market.

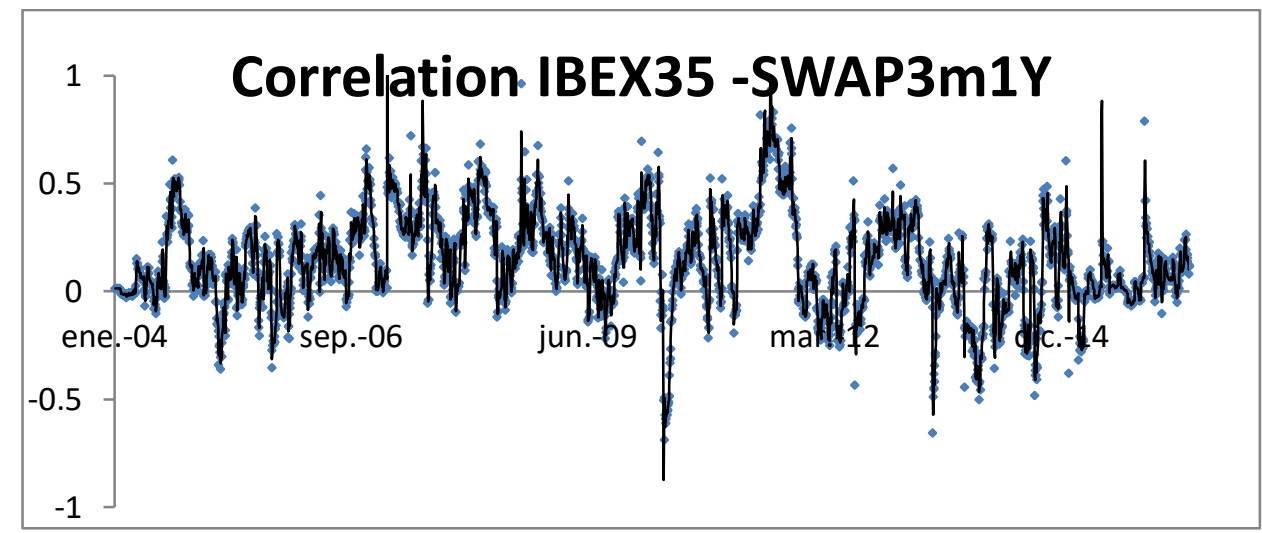

Source: Based on Matlab Simulation

Figure 10 Correlations IBEX -SWAP

On another hand, the DCC-GARCH model has shown that there is a transference of the volatility from the market to the interest rate (significant coefficients) and especially when the uncertainly is higher in the DAX30, CAD, IBEX-35 indexes (Robert N and William $\mathrm{R}$ White 1997). It may be since the monetary authority corrects interest rate deviations every day, and is normally based on the behavior of the banking system if the lending rate 
between banks increases, the capital those banks are willing to lend to commercial agents decreases. However, if the rate at which canary entities remain constant or the best scenario decreases, the banking entities will have more capital to make it available to commercial agents.

\section{References}

Big Banks Accused of Monopolizing Interest Rate-Swap Market Available (2015): https://www.bloomberg.com/news/articles/2015-11-26/big-banks-accused-ofmonopolizing-interest-rate-swap-market

Carsten Detken and Philipp Hartmann (2009), The Euro and International Capital Markets

Chan, K. C., Karolyi, G. A., Longstaff, F. A. and Sanders, A. B. (1992), 'An empirical comparison of alternative models of the short-term interest rate', The Journal of Finance 47(3), 1209-1227.

Dai, Q. and Singleton, K. J. (2000), 'Specification analysis of affine term structure models', The Journal of Finance 55(5), 1943-1978.

De La Torre Gallegos, A (1996): Operaciones de permuta financiera (swaps). Editorial Ariel, Barcelona.

Eduardo arango, JaimE albErto arroyavE, 2011. SwapS de taSa de interéS y de cruce de monedas como herramientaS de cobertura para laS empreSaS colombianas

European Central Bank (2015): Euro money market survey, September.

Fabio Fornari (2005), The rise and fall of US dollar interest rate volatility: evidence from swaptions

Fabio Fornari (2004): "Macroeconomic announcements and implied volatilities inswaption markets".

Goldman Named as Part of Interest-Rate Swap Antitrust Case (On-line)

Available (2016): https://www.bloomberg.com/news/articles/2016-05-06/goldman-saysit-was-named-in-interest-rate-swap-antitrust-case.

Hernández, C. (2014). Efectos Asimétricos de Shocks Fiscales en el Ciclo Económico.

Ho, T.S.Y. and S.B. Lee (1986), 'Term Structure Movements and Pricing Interest Rate Contingent Claims', The Journal of Finance, 41(5): 1011-29.

Hernández, C. (2014). Efectos Asimétricos de Shocks Fiscales en el Ciclo Económico.

Lorenzo Cappiello, Peter Hördahl, Arjan Kadareja and Simone Manganelli (2006), The Impact Of The Euro On Financial Markets

McCauley, R. (1997): The euro and the dollar. 
McCauley, R and P Wooldridge (2016): "Exchanges struggle to attract derivatives trading from OTC markets", BIS Quarterly Review, September, pp 33-4.

Martin Cihák y Srobona Mitra (2009), Adiós a la aureola -La crisis sacude a Europa

Martin, P., Rey, H. (1999), Financial super-markets: size matters for asset trade.

Michael G. Kollo (2005), Underwriter Competition And Gross Spreads In The Eurobond Market

Nelson, D and D Foster (1995), Filtering and forecasting with misspecified ARCH models II: making the right forecast with the wrong model.

Nelson, Charles R. and Siegel, Andrew F. (1987). "Parsimonious modeling of yield curves".

Paul R Masson and Bart G. Turtelboom (1997), Characteristics of the Euro, Demand for reserves and Policy Coordination under EMU

Ravi Bansal and Hao Zhou (2001), Term Structure of the interest rates with Regime Shifts.

Robert Engle1(1999), Dynamic Conditional Correlation -A Simple Class Of Multivariate Garch Models

Robert N McCauley (1997), The euro and European financial markets.

Robert N McCauley (2010), The euro and the liquidity of European fixed income markets

Triennial Central Bank Survey: OTC interest rate derivatives turnover. (2016),

Available (2017): https://www.bis.org/publ/rpfx18.htm

Triennial Central Bank Survey of foreign exchange and derivatives market activity in 2013

Available (2015): https://www.bis.org/publ/rpfx13.htm

Tse, Y., \& Tsui, C. (2002). A multivariate generalized autoregressive conditional heteroscedasticity model with time-varying correlations.

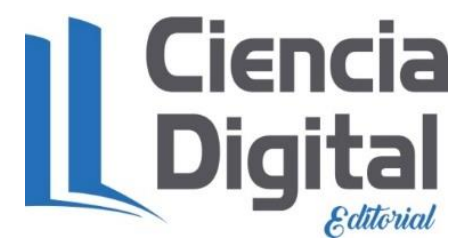




\section{PARA CITAR EL ARTÍCULO INDEXADO.}

Santillan Pashma, A. R. (2021). Analysis of transmission of conditional volatility from $\begin{array}{llll}\text { market risk } & \text { factors. } & \text { ConcienciaDigital, } & 4(2),\end{array}$ https://doi.org/10.33262/concienciadigital.v4i2.1700

\section{LCigital}

El artículo que se publica es de exclusiva responsabilidad de los autores y no necesariamente reflejan el pensamiento de la Revista Conciencia Digital.

El artículo queda en propiedad de la revista y, por tanto, su publicación parcial y/o total en otro medio tiene que ser autorizado por el director de la Revista Conciencia Digital.

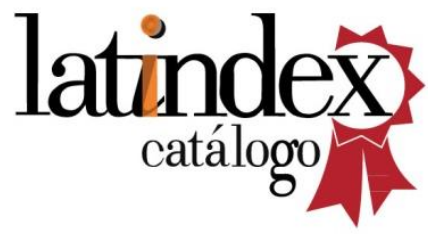

